\title{
Correlation between ovarian steroidogenesis and $\beta$-endorphin in the Lizard Uromastyx acanthinura: Immunohistochemical approach
}

\author{
Sadjia Hammouche ${ }^{1}$, Thérese Gernigon ${ }^{1}$, Jean Marie Exbrayat ${ }^{2}$ \\ ${ }^{1}$ Laboratoire de Recherche en Zones Arides, Equipe Reproduction des petits Vertébrés, \\ Faculté des Sciences Biologiques, Université des Sciences et de la Technologie de Houari Boumediene, \\ PB 39 El Alia, Bab Ezzouar, Alger. \\ ${ }^{2}$ Université de Lyon, Laboratoire de Biologie Générale, UCLy, Reproduction et développement comparé \\ EPHE, 25 rue du Plat, 69288 Lyon cedex 02, France.
}

\begin{abstract}
In Mammals, opioid peptides are involved in various physiological processes including the reproductive function. The knowledge of the distribution of $\beta$-endorphin, one of opioid peptides in Reptiles ovaries is very limited. Therefore, the present study used the lizard ovarian follicles to further elucidate the role of this peptide in steroidogenesis. In Uromastyx acanthinura, the localization of both this peptide and sex steroid hormone was investigated by the immunohistochemical approach. This technique was used to evaluate the distribution of these substances and their relationship. The $\beta$-endorphin is strongly distributed in the granulosa cells and oocyte cytoplasm of the previtellogenic follicles in sexually quiescent lizards (winter) when steroidogenesis was interrupted. In spring, the signal became weak, or even absent, in the vitellogenic and previtellogenic follicles. The granulosa cells of the previtellogenic follicles showed an important synthesis of $17 \beta$-estradiol. Females that did not undergo in vitellogenesis in spring showed the same profile than quiescent females of winter. These findings represent the first evidence of the presence of $\beta$-endorphin in the ovary of this lizard. The seasonal variations observed in the reproductive cycle suggest that this opioid peptide is involved in the modulation of seasonal steroidogenesis.
\end{abstract}

Key words: $\beta$-endorphin, steroidogenesis, ovary, Lizard, Uromastyx acanthinura

\section{Background}

Endocrine regulation of reproduction incorporates modulatory action of opioid peptides, which occurs at all the levels of the hypothalamo-pituitary-gonadal axis. Opioids affect this system mainly through the modulation of GnRH and LH secretion [1-7]. In addition, the $\beta$-endorphin participates to the control of reproductive function through a direct local action within reproductive tissues. The genes encoding for precursor (proopiomelanocortin) of this opioid peptide are expressed in the porcine granulosa cells [8] and several $\beta$-endorphins derived from this precursor have been detected in ovaries and follicular fluids in mammalian species [9-17] and lizard [18].

The changes of concentration of this peptide in the gonads of cyclic females $[10,14,16]$ imply that the ovarian production of opioid peptides is controlled by

Correspondence: SH: sadjiah@yahoo.fr

TG: tgernigon@yahoo.com JME: jmexbrayat@univ-catholyon.fr gonadotrophins. This suggestion is supported by findings that in rat ovaries, hCG and LH significantly increase the proopiomelanocortin mRNA expression [19] and the release of endorphin [16] and that FSH stimulates the secretion of endorphins by the porcine granulosa cells [13].

The reports pertaining to the influence of endorphin on steroidogenesis in mammals granulosa cells [13], theca interna cells [9], and luteal cells $[12,13,14,15,17]$ suggest that the opioid peptide exerts autocrine and/or paracrine effects in the ovary. The inhibitory effect of endorphin on synthesis of the estradiol and androgen was demonstrated in cells of porcine theca interna [20].

The information concerning the influence of the opioid peptides, acting through $\beta$-endorphin on reptilian ovarian steroidogenesis are very limited, the only study examined in the Lizard indicates an inhibitory local ovarian effect [21]. It was interesting to perform comparative studies on the engagement of $\beta$-endorphin in the modulation of ovarian steroidogenesis. The study examined the presence of the $\beta$-endorphin 
in the ovary of the desert lizard, Uromastyx acanthinura, at the different stages of folliculogenesis and in connection with steroidogenesis.

\section{Methods}

Chemicals. Mouse monoclonal antibody anti-17 $\beta$-estradiol (Biomeda), rabbit polyclonal antibodies anti-testosterone and antiprogesterone (Biomeda), rabbit polyclonal antibody anti-P450 aromatase (BioTrend), rabbit polyclonal antibody anti- $\beta$-endorphin (Chemicon) were used.

Animals. Adult female lizards (Uromastyx acanthinura) were collected in the arid region of north-western Sahara during the reproductive cycle in breeding (spring), post-reproductive (summer) and in sexual rest (winter) periods from 1999 to 2004. 50 females adults were used, 20 were captured during vitellogenesis (late May), 6 females were non vitellogenic (late May), 6 females were in post-reproductive period (July) and 18 females were in the sexual rest season (January). The animals were anaesthetised with intraperitoneal injection of $6 \%$ saline pentobarbital $\left(10^{-3} \mathrm{ml} / \mathrm{g}\right.$ of weight). A part of the removed ovaries were fixed with Bouin's fixative, dehydrated in graded alcohols and embedded in paraffin for $\beta$-endorphin immunohistochemical investigation. The other parts of ovaries were fresh frozen into liquid nitrogen and cut with a cryostat for detection of steroid hormones and P450 aromatase. Frozen and paraffin sections were cut and floated onto Super Frost slides.

Immunohistochemistry. The labelling was applied by the indirect immunohistochemical method using an Avidine Biotine Peroxidase detection system with the Dako LSAB2 kit. The frozen sections were incubated for $30 \mathrm{mins}$ at room temperature with the specific antibodies anti-17 $\beta$-estradiol, anti-testosterone, anti-progesterone, anti-P450 aromatase at a dilution of 1:100 in the blocking solution (goat serum) and the paraffin sections were incubated for the same time with anti$\beta$-endorphin antibody at a dilution of 1:400. Then all sections were rinsed two times in a bath of phosphate buffer saline for 5mins each and incubated with pre-diluted secondary antibody (anti-mouse IgG for $17 \beta$-estradiol labelling and anti-rabbit IgG for testosterone, progesterone, P450 aromatase and - $\beta$ endorphin detection) for 30mins at room temperature and then rinsed in the same buffer. The slides were incubated for streptavidine for $30 \mathrm{mins}$ at room temperature and rinsed in phosphate buffer saline. The labellings of steroid hormones and $\mathrm{P} 450$ aromatase were revealed in red with 3 amino- 9 ethyl-carbazole (AEC) and that of $\beta$-endorphin revealed in brown with 3,3diaminobenzidine (DAB). A control of specificity consisted in omitting the primary antiserum step to test for non-specific binding of secondary antibody to the tissue. The primary antibodies except anti- $\beta$ endorphin were also tested in the rat ovary [22].

\section{Results}

\section{Females captured in the breeding period}

In the vitellogenic females, steroidogenesis activity was in favour of $17 \beta$-estradiol biosynthesis. Two kinds of follicles were indeed present in the ovaries.

The vitellogenic follicles of $10-20 \mathrm{~mm}$ in size were abundant and showed a granulosa generally containing a single layer of small cells. The granulosa was partially stained with detection method of $17 \beta$-estradiol (Fig. 1), while intense staining of progesterone in all cells was shown (Fig. 2). $\beta$-endorphin was totally absent from granulosa (Fig. 3).
Both primary and secondary previtellogenic follicles were found. The maximal diameter of the latter was $1.5 \mathrm{~mm}$. In the previtellogenic granulosa, three cellular categories were observed: apical and basal small cells, intermediate cells and piriform cells. Only the granulosa was immunoreactive for $17 \beta$-estradiol and testosterone (Fig. 4) and the piriform cells appeared particularly well labelled (Fig. 5). The presence of the P450 aromatase in the piriform cells only indicated that these cells were the site of steroidogenesis (Fig. 6). $\beta$-endorphin was also invisible in the previtellogenic follicles (Fig. 7).

The atretic follicles were not very often observed and they were generally small in size. They contained a granulosa in regression process or even completely regressed. The cells invaded or not the follicular cavity and they were characterised by a positive staining of testosterone, $17 \beta$-estradiol and progesterone. The latter two steroids were detected in the theca but not always and testosterone was found in the follicular cavity. Some of the cells dispersed in the follicular cavity showed apoptotic nuclei. Contrarily to the vitellogenic and previtellogenic follicles, $\beta$-endorphin was present in the atretic follicles, and stained label appeared more particularly in the apoptotic granulosa cells (Fig. 8).

These results were different from those obtained in the females captured in the breeding period but without undergoing in vitellogenesis. The ovaries showed only some previtellogenic follicles at secondary and tertiary stages and the maximal diameter of which reached 4,5 $\mathrm{mm}$. This size was clearly the greatest compared to those observed during the seasonally anoestrus where the diameter did not exceed $3 \mathrm{~mm}$. The morphological pathway of these follicles remained similar but the $4.5 \mathrm{~mm}$ growth reached by these tertiary follicles generally observed at transition (transitory stage between previtellogenic and vitellogenic follicles) was not accompanied by structural and physiological changes. A slowing down follicular prevents the normal functional evolution of the tertiary follicles to transitory follicles and then to vitellogenic follicles. In the non vitellogenic females, the steroidogenesis was interrupted, neither steroid hormones nor P450 aromatase were present when $\beta$-endorphin was strongly distributed in the granulosa piriform cells and peripherical oocyte cytoplasm wathever the stage of previtellogenesis and appeared relatively more important in the tertiary follicles. $\beta$-endorphin seemed to move from the granulosa cells to the oocyte I where it gets concentrated in the peripherical oocyte cytoplasm. The atretic follicles were totally absent in these females.

\section{Females captured in the post-reproductive period}

In the post-reproductive females, only previtellogenic follicles remained present. Among them numerous 
primordial and primary follicles of $2 \mathrm{~mm}$ in maximal size were observed. The ovaries were also characterized by the abundance of residual bodies of corpus luteum and atretic follicles.

The primordial follicles were not stained after application of anti-P450 aromatase and all the antibodies against the steroid hormones investigated.

In the most of primary and secondary follicles, the granulosa cells exhibited a positive reactivity to $17 \beta-$ estradiol and testosterone but with a weak signal in comparison with the previtellogenic follicles obtained in vitellogenic females (Fig. 9). Only piriform cells were stained. The signal corresponding to progesterone which appeared more intense than that of $17 \beta-$ estradiol and testosterone (Fig. 10). In the rest of primary and secondary follicles, the steroidogenic activity was almost non-existent.

A parallel to this limited hormonal synthesis but which seems more in favour of progesterone synthesis than of $17 \beta$-estradiol, the $\beta$-endorphin appeared with diffuse and weak signal in the granulosa of primary and secondary follicles and particularly in the piriform cells (Fig. 11). All primordial follicles were devoid of label except those which were in full proliferation phase at primary follicles and which differentiate piriform cells.

The atretic follicles were observed at all stages of previtellogenesis and showed the same immunohistochemical characteristics of steroid hormones as those of vitellogenic females. The atretic follicles were immunoreactive to $\beta$-endorphin as in the vitellogenic females and the labelling was found in the degenerative granulosa cells.

The residual bodies of corpus luteum dispersed in the ovarian stroma were composed of lutein cells of 7$16 \mu \mathrm{m}$ in size with an eccentric and dense nucleus and a cytoplasm charged with yellow pigment. The lutein cells were immunoreactive to $17 \beta$-estradiol (Fig. 12), testosterone and P450 aromatase (Fig. 13) but they were not reactive with anti-progesterone (Fig. 14).

\section{Females captured in winter period}

In winter females, ovary contained essentially secondary and tertiary stages of previtellogenic follicles which reached $3 \mathrm{~mm}$ in diameter. The steroidogenic activity was interrupted in all the stages of previtellogenesis; no positive labelling to P450 aromatase and steroid hormones investigated was detected (Fig. 15).

During hibernation, $\beta$-endorphin became widely dispersed into the piriform, intermediate and theca cells and oocyte I at all the follicular stages (Fig. 16 and Fig. 17). The signal became more pronounced in the piriform cells and peripherical oocyte cytoplasm and strongly granular than previously. These immunohistochemical results remind the observations obtained at in spring anoestrus females where any steroids detection was observed whereas $\beta$-endorphin was well expressed.

\section{Discussion}

The expression of the $17 \beta$-estradiol and P450 aromatase in the granulosa piriform cells of Uromastyx acanthinura as well as their absence in the cells of theca interna indicate a functional differentiation in the 17 $\beta$-estradiol biosynthesis and strenghthen the bicellular theory [23] which was emitted in the rat and mouse [24]. The absence of testosterone detection in the theca interna cells could be the sign of a rapid passage of this steroid from the theca to the granulosa rather than a conversion of minor importance of androstenodione into testosterone in the theca interna since the testosterone is widely detected in the granulosa. The $17 \beta$-estradiol synthesis may not involve the functional cooperation between the theca and granulosa cells, as this was noted in some species such as chicken where P450 aromatase was expressed only in the theca [25]. In the pig [26], fish [27] and lizard [28], the P450 aromatase was found both in the theca and granulosa.

In Uromastyx acanthinura, the expression of P450 aromatase in the piriform cells, describe them as steroidogenic cells in addition to their already known nourishing role [29]. The $17 \beta$-estradiol mainly produced by previtellogenic follicles during vitellogenesis was necessary for the synthesis of hepatic vitellogenin and for maturation of follicles. $17 \beta$-estradiol exerts an autocrine and paracrine action in these previtellogenic follicles. A part of this action is mediated by the classical estrogen receptor which is detected in the piriform cells and at lesser degree in the rest of the follicular cells [30]. In the Mammals, the synergic role of $17 \beta$-estradiol with FSH in the P450 aromatase activation is well established fact [31] and the classical estrogen receptor may be responsible [32-36].

During the annual reproductive cycle of Uromastyx acanthinura, $\beta$-endorphin appears in the post-reproductive period when the steroids biosynthesis was reduced and it becomes pronounced in the sexually rest period during the absence of steroidogenesis, and then totally disappears in the vitellogenic follicles or in the previtellogenic follicles concomitantly with a maximal synthesis of steroids. The presence of this peptide in the ovarian follicles thus seems inversely correlated with their steroidogenic activity. The persistence of the $\beta$-endorphin in the spring anoestrus females simultaneous with altered steroidogenesis strenghthens our interpretation.

The signalisation of the $\beta$-endorphin at the ovarian level confirms the previous results obtained in mammalian species in the human $[9,10]$, ovins [11], pig $[12,13]$, rat [14-16], mouse [17] and in the lizard Podarcis sicula sicula [18]. In Mammals, the presence of $\beta$-endorphin is negligible in the granulosa cells; a faint label appears in secondary and antral stages of the folliculogenesis in the human [9] and in the rat [14] 

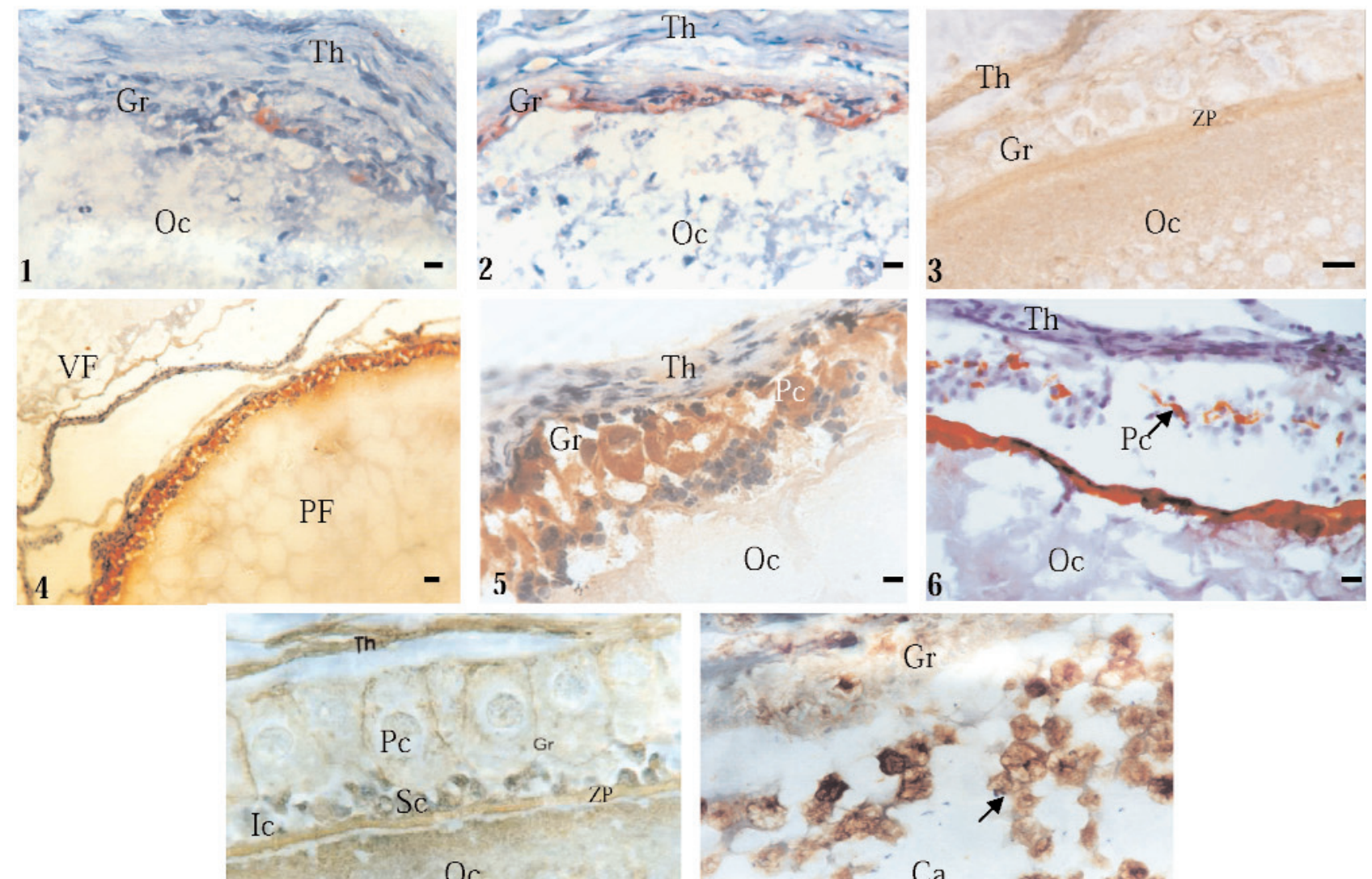

$$
7
$$

Oc

$$
-
$$

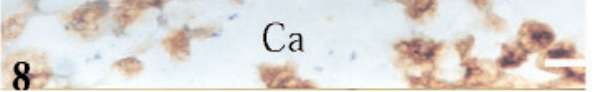
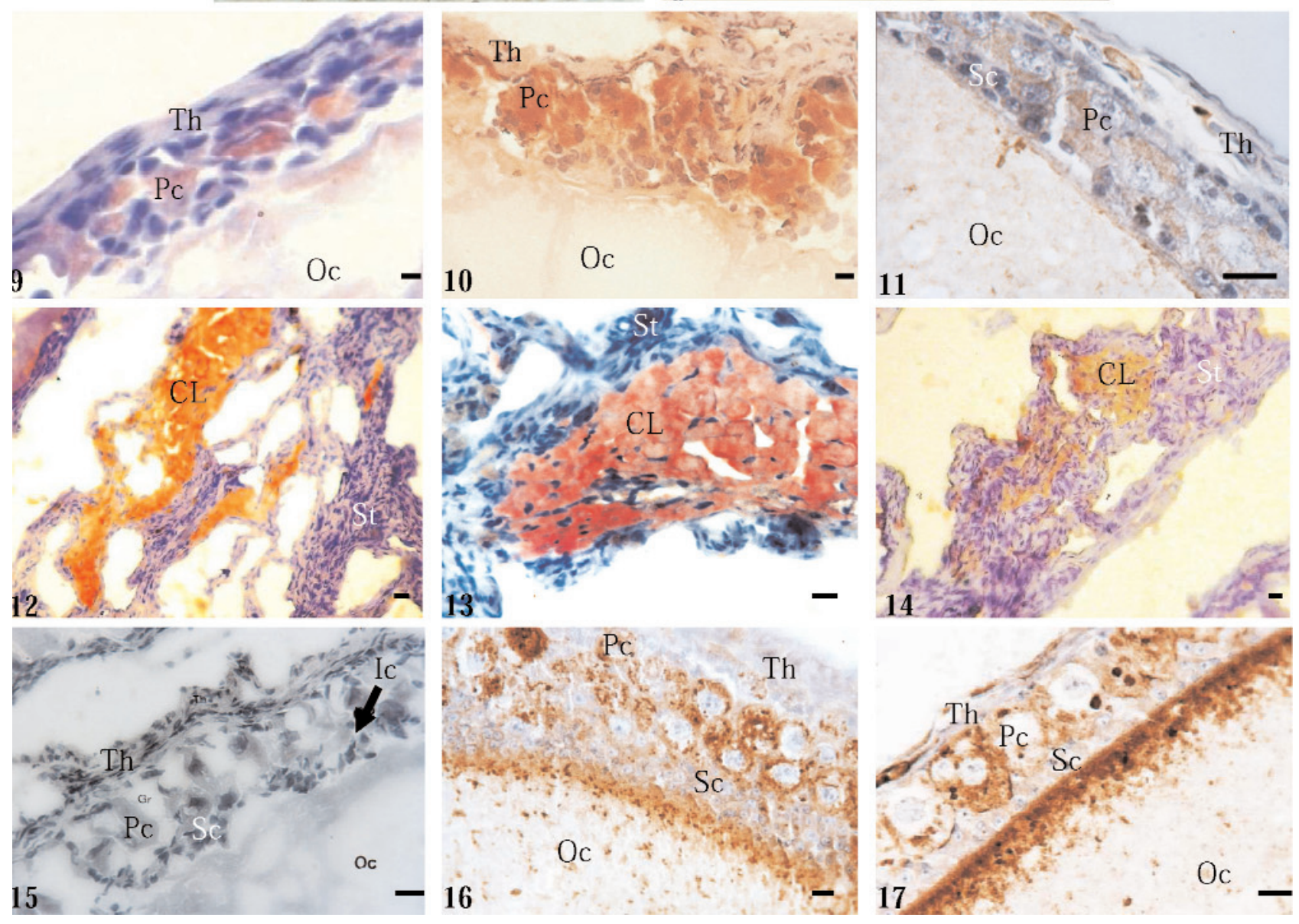
and becomes important only as from the preovulatory stage $[9,10,14,17]$. These results do not match with those obtained in Uromastyx acanthinura because this opioid peptide was strongly expressed in the follicular cells and completely absent in the mature vitellogenic follicle.

Changes in the concentration of this peptide in gonads of mammalian cyclic females $[14,10,16]$ imply that the ovarian production of opioid peptides is controlled by gonadotrophins. This suggestion is supported by findings that both hCG and LH significantly increase the proopiomelanocortin mRNA expression [19] and the release of endorphin [16] from rat ovaries and FSH stimulates endorphin secretion by porcine granulosa cells [13].

Our observations were supported by more recent studies which indicate a suppressor effect of $\beta$-endorphin on steroidogenesis. Indeed, the $\beta$-endorphin and its $\mu$-receptor agonist induce in vitro the suppression of the androgen and estradiol in the porcine theca interna cells [20]. A more recent study revealed an important expression of the proopiomelanocortin genes in the porcine granulosa cells which makes them a major source of opioid peptides [8].

In the lizards, some available studies show conflicting results. In male Podarcis sicula, $\beta$-endorphin shows an elevated level in the sexual rest [37] and inhibitory effect on the androgen secretion [38]. But in the female, this peptide does not significantly change during the reproductive cycle and induces a rather positive action on the 17ß-estradiol secretion [18]. The study realised in the lizard Mabuya carinata was interesting because it confirms the inhibitory effect of the $\beta$-endorphin on the seasonal ovarian recrudescence which was obtained with or without the FSH which proves a local action [21]. $\beta$-endorphin apparition in the Uromastyx acanthinura ovary at post-reproductive period was a practically comparable phenomenon to the result observed in the amphibian Rana esculenta in which increases at the end of breeding season when the ovarian weight and the follicular diameter were weaker [39].

\section{Conclusion}

The inverse correlation between the $\beta$-endorphin and the hormonal activity in the ovarian lizard Uromastyx acanthinura suggests an inhibitory role on steroidogenesis and thus a modulator effect of the ovarian seasonality. The $\beta$-endorphin seems strictly linked to sexual rest. It would then be interesting to analyse in more details the mechanism of the $\beta$-endorphin action in the local control of the steroidogenesis in Uromastyx acanthinura.

Competing interests: The authors declare that they have no competing interests.

Author's contributions: SH carried out the experiments and wrote the manuscript. GSTh and JME discussed the results and corrected the manuscript. All authors read and approved the final manuscript.

Acknowledgments: The study is part of Doctorat research thesis submitted to Sciences and Technology University, Algiers, Biological Sciences Institute. The financial support through programme accord 00 MDU 489 is gratefully acknowledged.

\section{References}

[1] Brooks AN, Haynes NB, Yang K, Lamming GE. Ovarian steroid involvement in endogenous opioid modulation of LH secretion in seasonally anoestrus mature ewes. J Reprod Fert 1986, 76:709-715.

[2] Yang K, Haynes NB, Lamming GE, Brooks AN. Ovarian steroid hormone involvement in the endogenous opioid modulation of LH secretion in mature ewes during the breeding and non-breeding seasons. J Reprod Fert 1988, 83:129-139.

[3] Walsh JP, Clarke IJ. Blockage of the oestrogen-induced luteinizing hormone surge in ovariectomized ewes by a highly selective opioid mu-receptor agonist: evidence for site of action. Neuroendocrinol 1998, 67(3):164-170.

[4] Faletti AG, Mastronadri CA, Lomniczi A, Seilicovich A, Gimeno M, McCann S, Rettori V. $\beta$-endorphine blocks luteinizing hormone releasing hormone by inhibitory the nitricoxidergic pathway controlling its release. Proc Natl Acad Sci 1999, 96:1722-1726.

[5] Whisnaut CS, Goodman RL. Effects of an opioid antagonist on pulsatile luteinizing hormone secretion in the ewe vary with changes in steroid negative feedback. Biol Reprod 1988, 39:1032-1038.

[6] Veldhuis JD, Rogol AD, Johnson ML. Endogenous opiates modulate the pulsatile secretion of biologically activate

Figs. 1-8. Vitellogenic females. Fig. 1. Labelling of vitellogenic follicle with 17ß-estradiol; partial staining in the granulosa (Gr). Fig. 2. Labelling of vitellogenic follicle with progesterone; all granulosa cells are stained. Fig. 3. Labelling of vitellogenic folliclewith $\beta$-endorphin; showing negative staining. Fig. 4. Labelling of previtellogenic follicle (PF) with 17ß-estradiol. Fig. 5. Labelling of previtellogenic follicle with 17ß-estradiol; intense staining in the piriform cells $(\mathrm{Pc})$ of the granulosa. Fig. 6. Labelling of previtellogenic follicle with P450 aromatase; staining only in the piriform cells. Fig. 7. Labelling of previtellogenic follicle with ß-endorphin; showing negative staining. Fig. 8. Labelling of atretic follicle with $\beta$-endorphin; positive staining in the apoptotic cells (arrow). Figs. 9-14. Post-reproductive females. Fig. 9. Labelling of previtellogenic follicle with 17ß-estradiol; weak signal in the piriform cells. Fig. 10. Labelling of previtellogenic follicle with progesterone; intense signal in the piriform cells. Fig. 11. Labelling of previtellogenic follicle with $\beta$-endorphin; a diffuse signal appears in the piriform cells. Fig. 12. Positive labelling with 17ß-estradiol of residual body of corpus luteum (CL). Fig. 13. Positive labelling with $P 450$ aromatase of residual body of corpus luteum. Fig. 14. Negative labelling with progesterone of residual body of corpus luteum. Figs. 15-17. Winter females. Fig. 15. Labelling of previtellogenic follicle with 17ß-estradiol; showing negative staining. Fig. 16. Labelling of previtellogenic secondary follicle with ß-endorphin; strong signal in the piriform cells and oocyte I (Oc), thestaining was granular. Fig. 17. Positive labelling of previtellogenic tertiary follicle with B-endorphin. Legends: Ca - follicular cavity, Ic - intermediate cell, Sc - Small cell, St - ovarian stroma, $\mathrm{Th}$ - Theca, VF- vitellogenic follicle, $\mathrm{ZP}$ - zona pellucida. Bar of calibration= $10 \mu \mathrm{m}$ (Figures: 1, 2, 3, 5, 6, 7, 8, 9, 10, 11, 13, 14, 15, 16, 17); $=20 \mu \mathrm{m}$ (Figures: 4, 12). 
luteinizing hormone in man. J Clin Investigation 1983, 72:2031-2040.

[7] Gore AC, Terasawa E. Neural circuits regulating pulsatile luteinzing hormones release in the female Guinea-Pig: Opioid, Adrenergic and serotonergic interactions. J Neuroendocrinol 2001, 13(3):239-246.

[ 8] Staszkiewicz J, Skowronski MT, Kaminski T, Siawrys G, Krazinski BE, Kusmider M, Przala J, Okrasa S. Expression of proopiomelanocortin, proenkephalin, and prodynorphin genes in porcine theca and granulosa cells. Ani Reprod Sci 2007, 101(1-2): 97-112.

[9] Aleem FA, Omar RA, El-Tabbakh GH. Immunoreactive $\beta$ endorphin in human ovaries. Fert Ster 1986, 45(4):507-511.

[10] Petraglia F, Dimeo G, Storchi R, Segre A, Facchinetti F, Szalay S, Volpe A, Genazzani AR. Proopiomelanocortin-related peptides and methionine enkephalin in human follicular fluid: changes during the menstrual cycle. Amer J Obstet Gynecol 1987, 157(1):142-146.

[11] Lim AT, Lolait S, Barlow JW, Wai Sumo O, Zois I, Toh BH, Funder JW. Immunoreactive $\beta$-endorphine in sheep ovary. Nature 1983, 303(23):709- 711.

[12] Prazala J, Kaminski T, Siawrys G, Okrasa S. Large luteal cells are the source of immunoreactive $\beta$-endorphine in the pig: effects of hCG and TNFA on its secretion by luteal cells in vitro. Endocrine regulation 1999, 33:117-123.

[13] Kaminski T, Siawrys G, Bogacka I, Przala J. The physiological role of $\beta$-endorphine in porcine ovarian follicles. Reprod Nutr Dev 2000, 40:63-75.

[14] Lolait SJ, Autelitano DJ, Lim AT, Smith A I, Toh BH, Funder JW. Ovarian immunoreactive beta-endorphin and estrous cycle in the rat. Endocrinol 1985, 117(1):161-168.

[15] Lolait SJ, Autelitano DJ, Marwick AJ, Toh BH, Funder JW. Co-expression of vasopressin with beta-endocrphine and dynorphin in individual cells from the ovaries of Brattleboro and long-evans rats: immunocytochemical studies. Peptides 1986, 7(2):267-276.

[16] Lovegren ES, Zimniski SJ, Puett D. Ovarian contents of immunoreactive beta-endorphin and alpha-N-acetylated opioid peptidess in rats. J Reprod Fert 1991, 91(1):91-100.

[17] Shaha C, Margioris A, Liotta AS, Krieger DT, Bardin CW. Demonstration of immunoreactive beta-endorphin and gamma 3 melanocyte stimulating hormone-related peptides in the ovaries of neonatal, cyclic, and pregnant mice. Endocrinol 1984, 115(1):378-384.

[18] Polzonetti-Magni A, Facchinetti F, Carnevali O, Mosconi G, Pestarino M, Vallarino M, Ciarcia G. Presence and steroidogenetic activity of $\beta$-endorphine in the ovary of the lizard, Podarcis sicula sicula Raf. Biol Reprod, 1994, 50:1059-1065.

[19] Melner MH, Young SL, Czerwiec FS, Lyn D, Puett D, Roberts JL, Koos RD. The regulation of granulosa cell proopiomelanocortin messenger ribonucleic acid by androgens and gonadotropins. Endocrinol 1986, 119:2082-2088.

[20] Kaminski T, Siawrys G, Bogacka I, Okrasa S, Przala J. The regulation of steroidogenesis by opioid peptides in porcine theca cells. Ani Reprod Sci 2003, 78:71-84.

[21] Ganesh CB, Yajurvedi HN. $\beta$-endorphine disrupts seasonal and FSH induced ovarian recrudescence in the lizard Mabuya carinata. Gen Comp Endocrinol 2003, 133:305-313.

[22] Boubekri A, Gernigon-Spychalowicz T, Khammar1 F, Exbrayat JM. Histological and immunohistological aspects of the ovarian cycle of the algerian wild sand rat, Psammomys obesus Cretzschmar, 1828. Folia Histochemica Cytobiologica 2007, 45(suppl 1):41-49.

[23] Magoffin DA. Ovarian theca cell. Internatl J Biochem Cell Biol 2005, 37:1344-1349.

[24] Ishimura K, Yoshinaga-Hirabayashi T, Tsuri H, Fujita H, Osawa Y. Further immunocytochemical study on the localization of aromatase in the ovary of rats and mice. Histochemistry 1989 , 90(6):413-416.

[25] Nitta H, Osawa Y, Bahr JM. Immunolocalization of steroidogenic cells in small follicles of the chicken ovary: Anatomical arrangement and location of steroidogenic cells change during follicular development. Domestic Ani Endocrinol 1991, 8(4):587-594.

[26] Shores EM, Hunter MG. Immunohistochemical localization of steroidogenic enzymes and comparison with hormone production during follicle development in the pig. Reprod Fert Dev 1999, 11(6):337-344.

[27] Sunobe T, Nakamura M, Kobayashi Y, Kobayashi T, Nagahama Y. Aromatase immunoreactivity and the role of enzymes in steroid pathways for inducing sex change in the hermaphrodite gobiid fish Trimma okinawae. Comp Biochem Physiol 2005, Part A (141):54-59.

[28] Endo D, Park MK. Molecular cloning of P450 aromatase from the leopard gecko and its expression in the ovary. J Ster Biochem Mol Biol 2005, 96:131-140.

[29] Hammouche S. Etude histo-cytologique des variations saisonnieres de l'appareil reproducteur femelle chez le lézard, Uromastyx acanthinura. These de Magister. Université des Sciences et Technologie Houari Boumediene Alger, Faculté des Sciences Biologiques; 1997.

[30] Hammouche S, Gernigon Spychalowicz TH, Exbrayat JM. Immunolocalization of estrogens and progesterone receptors within the ovary of the lizard Uromastyx acanthinura from vitellogenesis to rest season. Folia Histochemica Cytobiologica 2007, 45 (Supp 1): 23-27.

[31] Adashi EY, Hsueh AJW. Estrogens augment the stimulation of ovarian aromatase activity by follicle stimulating hormone in cultured Rat granulosa cells. J Biol Chemistry 1982, 257(11):6077-6083.

[32] Billiar RB, Loukides JA, Miller MM. Evidence of the presence of estrogen receptor in the ovary of baboon (Papio anubis). J Clin Endocrinol Metabol 1992, 75 (4):1159-1165.

[33] Hutz RJ, Wagner N, Krause P, Fisher C, Syed N, Dierschke DJ, Monniaux D, Tomanek M. Localization of estrogen receptors in rhesus monkey ovary. Amer J Primatol 1993, 31 (4):299-309.

[34] Suzuki T, Sasano H, Kimura N, Tamura M, Fukaya T, Yajima A, Nagura H. Immunohistochemical distribution of progesterone, androgen and oestrogen receptors in the human ovary during the menstrual cycle: relationship to expression of steroidogenic enzymes. Hum Reprod 1994, 9(9):1589-1595.

[35] Iwai T, Nanbu Y, Iwai M, Taii S, Fujii S, Mori T. Immunohistochemical localization of oestrogen receptors and progesterone receptors in the human ovary throughout the menstrual cycle. Virchows Arch Pathol Anat Histopathol 1990, 417(5):369-375.

[36] Saunders PTK, Millar MR, Williams K, Macpherson S, Harkiss D, Anderson RA, Orr B, Groome NP, Scobie G, Fraser HM. Differential expression of estrogen receptor $\alpha$ and $\beta$ and androgen receptor in the ovaries of Marmosets and humans. Biol Reprod 2000, 63:1098-1105.

[37] Ciarcia G, Facchinetti F, Vallarino M, Pestarino M, Paolucci M, Cardone A, Fasano S, Pierantoni R, Genazzani AR. Opioid peptides and testicular activity in the lizard Podarcis sicula sicula Raf. J Endocrinol 1994, 143:565-571.

[38] Ciarcia G, Cardone A, Paolucci M. In vitro effects of beta endorphin on testicular release of androgens in the lizard Podarcis sicula sicula Raf. Mol Reprod Dev 1996, 45:308-312.

[39] Facchenetti F, Genazzani AR, Pestarino M, Vallarino M, Pierantoni R, Fasano S, D'Antonio M, Carnevali O, Mosconi G, Polzonetti-Magni A. Ovarian opioids and the reproductive cycle of the frog Rana esculenta. Life Sci 1992, 50(19):1389-1398. 